\title{
REFERENSI MATA KULIAH TEORI BELAJAR DAN PEMBELAJARAN
}

Judul Buku

Pengarang

Kota

Penerbit

Tahun

Jumlah Halaman

Referensi MKDK

Dosen Pengampu

\author{
: Behaviour in School: Theory and Practice for Teachers \\ : Louise Porter \\ : Buckingham, Philadelphi \\ : Open University Press \\ : 2000 \\ $: 331$ \\ : Teori Belajar dan Pembelajaran \\ : Dra. Nurbiana Dhieni, M.Psi \\ Sri Indah Pujiastuti, M.Pd
}

Buku ini membahas tentang tingkah laku di sekolah secara teoritis dan praktis. Buku ini penting dipelajari oleh praktisi pembelajaran seperti guru, pengasuh, pendidik, pamong, instruktur, dosen. Buku ini mengungkapkan teori-teori yang berkaitan dengan pembelajaran dan aplikasinya di sekolah. Diharapkan dengan mempelajari tingkah laku di sekolah, guru dapat memahami perilaku anak yang berbeda-beda dalam belajar sehingga guru dapat memberikan stimulasi yang berbeda pula untuk setiap individu.

Tingkah laku di sekolah secara teoritis dan praktis ini lebih menyoroti pada tingkah laku anak dalam belajar. Setiap anak memiliki temperament, gaya belajar, latar belakang keluarga, pola dan waktu pertumbuhan/perkembangan yang berbeda. Dengan perbedaan yang ada pada anak-anak, guru dapat memilih pendekatan teori yang cocok untuk setiap anak. Di dalam menghadapi anak, guru tidak selalu menggunakan satu pendekatan saja. Kadang-kadang guru dapat memodifikasi teori-teori yang ada menjadi sebuah pendekatan yang lebih praktis diterapkan dan cocok untuk anak-anak. Teori-teori yang ada ini merupakan sebuah tawaran berdasarkan filosofi pendidikan. Sudah saatnya guru memperbaharui pola pembelajaran tradisional, yaitu selalu berpusat pada guru menjadi pembelajaran aktif dalam arti berpusat pada anak

Guru berperan sebagai contoh teladan, motivator dan fasilitator. Guru tidak perlu berbicara keras dan banyak bicara, tetapi perbuatan yang baik adalah yang pertama, penting dan harus dilakukan agar anak dapat meniru. Semua perbuatan anak bergantung pada contoh teladan guru dalam berperilaku. Kalau guru salah dalam berucap dan berbuat, maka anakpun akan meniru kesalahan tersebut, dan jika kesalahan tersebut terbiasa dilakukan, maka akan sangat sulit mengubah perilaku pada perkembangan anak selanjutnya. Guru juga perlu memberikan dorongan dan dukungan yang positif ketika anak meminta atau tidak meminta bantuan. Dukungan guru ini merupakan pijakan pertama untuk anak dalam mempelajari segala hal yang ingin diketahuinya. Guru tidak perlu memaksakan, membujuk, dan memerintahkan anak untuk berbuat sesuatu. Anak lebih mengetahui apa yang dia butuhkan. Guru hanya menyediakan fasilitas yang dibutuhkan anak dengan kriteria aman, nyaman, menarik, sesuai dengan tingkat perkembangan. Guru hanya membimbing dan mengawasi anak ketika anak menggunakan fasiltas pembelajaran. Guru dapat mendiskusikan segala hal yang berkaitan dengan pembelajaran bersama anak, misalnya menawarkan peraturan saat belajar dan berusaha melaksanakan segala konsekwensi yang harus dipenuhi ketika peraturan tersebut dilakukan atau tidak dilakukan oleh anak-anak dan guru. Pembelajaran demikian sangatlah demokratis untuk mendidik anak berpikir kritis, kreatif, dan eksploratif. Pandangan semacam ini dapat dilihat dan dikaitkan pada teori-teori yang ditawarkan berikut ini:

\section{Bagian 1: The Theories}

1. Introduction has key points: (1) theories allow us to organize our ideas and therefore to be clearer about our practices. They empower us, (2) the theories covered in this text differ in their goals for school discipline, ranging from the managerial function of maintaining order so that learning occur, to four educational function of teaching students self-discipline, emotional self-control, cooperation and integrity, (3) with any these goals as their basis, the theories differ in terms of the relatives status of teachers and students

Pendekatan disiplin yang diterapkan pada anakanak bergantung pada keyakinan guru pada anakanak, yaitu cara anak belajar, tujuan mendisiplinkan anak, penjelasan tentang tingkah laku yang mengganggu, cara guru memberikan 
kepercayaan pada anak-anak untuk melatih diri. Keyakinan ini akan menghasilkan pandangan tentang peran guru sebagai control atau arahan. Pada saat guru sadar akan keyakinannya dan terbiasa dengan teori tingkah laku anak, maka guru dapat meng-generalisasikan respon yang sama. Dengan hal ini, guru akan menguasai anakanak tidak hanya apa yang dilakukan oleh anakanak tetapi juga mengapa anak-anak melakukannya.

2. The Limit - Setting Approaches has key points: (1) the assertive teacher has a right and a duty to enforce order so that teaching and learning can be accomplished, (2) to encourage their cooperation, you will develop warm relationships with students, (3) to maximize their ability to abide by them you will teach students the rules, (4) positive recognition and incentives build cooperation, (5) you will apply graded consequences for serious or repeated disruptions.

Canter dan Canter (1992), dan Jones (1987a, 1987b) lebih jelas merencanakan disiplin bahwa guru dapat membatasi tingkah laku anak untuk merawat, mendidik, dan membelajarkannya. Disarankan, guru hendaknya tegas dalam berkatakata dan memberikan keterangan, memberikan kehangatan dan dukungan kepada anak-anak. Guru sebaiknya mengajarkan aturan dan memberikan hadiah secara personal dan formal sebagai pengakuan dan pendorong bagi anakanak. Jika tingkah laku yang mengganggu terjadi, sebaiknya guru membatasi dan meminta persetujuan kepada anak-anak jika hal ini dianggap sebagai kekurangan. Untuk membantu anak-anak, guru hendaknya menyesuaikan rencana dengan kebutuhan individu (anak-anak). Guru dapat memberikan konseling pada anakanak di luar jam pelajaran, dimulai dengan menanyakan sesuatu persoalan dan alasan anakanak memunculkan perilaku yang tidak sesuai dengan peraturan. Guru dapat membantu anak dengan beberapa cara seperti mengajak anak untuk menghindarkan diri dari kesulitan, memberikan bantuan akademik, atau memperbaharui komitmen untuk memberikan pengakuan positif. Guru hendaknya melihat dukungan orangtua dan administrasi sekolah ketika menghadapi masalah disiplin yang sulit. Canter dan Canter (1992) mengingatkan, guru hendaknya menggunakan rencana disiplin sebagai alat atau peraturan untuk menilai keadaan anak-anak secara individual.
3. Applied Behaviour Analysis has key points: (1) behaviour is controlled by the response it receives (its consequence). Thus, if you want to increase the rate of a behaviour, you must follow it with a positive consequence, and if you want to reduce its rate, you must follow it with a negative consequence, (2) the environment (antecedents) can also make behaviour more or less likely to occur, (3) reinforcers and punishment vary in intrusiveness (which is the extent to which they interrupt teaching) and restrictiveness (the extent to which teachers apply external control to students).

Analisis penerapan tingkah laku berpendapat bahwa tingkah laku manusia berdasarkan hukum, yaitu dapat diprediksikan melalui pengamatan keadaan di sekitarnya. Tingkah laku yang diikuti oleh konsekwensi merupakan nilai penerima dan akan meningkatkan seringnya tingkah laku tersebut muncul; tingkah laku yang diikuti konsekwensi negatif akan menurun; kondisi terdahulu di bawah kendali konsekwensi positif atau negatif rata-rata akan memperoleh perubahan tingkah laku yang kuat. Penerapan analisis tingkah laku di sekolah dapat dimulai dengan mendefinisikan, mengamati, dan mencatat tingkah laku anak-anak. Pada saat guru akan mengubah tingkah laku anak-anak, yang pertama adalah mengubah kondisi anak-anak di bawah kendali guru. Ini yang disebut persiapan, kemudian guru akan mengubah konsekwensi tingkah laku sehingga penguatan tidak selalu diberikan. Pada konsekwensi administrasi, guru akan mulai dengan pendekatan penguatan tingkah laku untuk meningkatkan tingkah laku positif, menggunakan penguatan alami yang mudah diikuti dan akan menguatkan beberapa hal tingkah laku negatif (perbedaan penguatan). Jika terdapat tingkah laku keras kepala yang lain, maka guru dapat menggunakan hukuman atau menurunkan prosedur dibawah kondisi yang keras/tegas pula. Metode konsekwensi terdiri dari: (1) prosedur penguatan: penguatan alami, penguatan diri, penguatan administrasi - orang dewasa, (2) prosedur penurunan: latihan perbedaan, koreksi sederhana, hukuman diri, perbedaan penguatan, kejenuhan stimulus, menghilangkan tingkah laku, penarikan diri dari stimulus positif (hukuman tipe 2), koreksi lebih, kehadiran keengganan stimulus (hukuman tipe 1), latihan tingkah laku negative.

4. Cognitive-Behavioursm has key points: (1) cognitive approaches aim to teach students effective ways of 
dealing with problems independently of you. They promote self - control, (2) success at any task depends on the environment, students' beliefs about themselves, their problem - solving skills, ability to do the task and ability to organize themselves to complete it, (3) cognitive restructuring can help both teachers and students remain in control of their own behaviour and emotion, reducing stress and increasing their personal effectiveness.

Teori tingkah laku kognitif memfokuskan pada pengelolaan diri anak dan menawarkan beberapa saran untuk guru dalam mengelola pikiran anak dan menggunakan pendekatan konsekwensi dalam pembelajaran. Teori ini ditujukan pada sikap anak-anak dalam tugas-tugas pembelajaran atau pemenuhan tingkah laku dan kemampuan anak dalam mengorganisasikan diri untuk mencapai standard pendekatan. Tujuan teori tingkah laku kognitif adalah untuk menjadikan ketidaktergantungan anak pada orang dewasa di dalam mengelola tingkah lakunya. Rasionalnya adalah mempromosikan pengelolaan diri untuk meningkatkan motivasi anak dengan mengikuti harapan; konsistensi keyakinan (seperti anak selalu memonitor tingkah lakunya, dimanapun guru berada); untuk meningkatkan kemampuan baru secara umum; mempertinggi efektivitas program tingkah laku; dan untuk membebaskan guru dari pengelolaan tingkah laku (Alberto dan Troutman, 1999; Kaplan dan Carter, 1995; Zipoli dan Melloy, 1997). Ketika guru mengajarkan anak restrukturisasi kognitif, guru akan mengkontribusikan kesehatan mental seperti kemampuan anak dalam mengamati norma-norma kelas (Kaplan dan Carter, 1995).

5. Neo - Adlerian Theory has key points: (1) the neo adlerians aim to increase student's sense of belonging and subsequent appropriate behaviour by establishing democratic relationship within the classroom that are based on mutual respect, cooperation and encouragement, (2) disruptive behaviour represents a faulty decision: disruptive students have selected an inappropriate way to meet their appropriate goal of seeking to belong in the group, (3) you can identify the goals of students disruptive behaviour by noting how you feel and respond to the behaviour, and how students respond to correction. Following this, your aim will be to guide students to satisfy the same goal through more appropriate behaviour.

Penulis teori neo adlerian mendasarkan pendekatannya pada keyakinan bahwa anak- anak berjuang dalam lingkungan sosialnya. Jika anakanak merasa berkecil hati dengan kemampuannya dalam tingkah laku prososial, maka anak akan memiliki tingkah laku antisosial. Peran guru adalah membina hubungan yang demokrasi di kelas dengan menerima semua anak, mengurangi persaingan di antara anak-anak dan mendorong anak-anak dalam belajar. Kunci prinsip adalah mengajarkan anak untuk menerima tanggung jawab atas tingkah laku sendiri melalui dorongan, kontrak, dan tugas atau konsekwensi logis. Guru mengakses motivasi anak dan mengarahkan aksinya dalam tingkah laku prososial dengan tujuan kepuasan anak.

6. Humanism has key points: (1) you will promote students' achievement and considerate behaviour when you nurture their emotional needs and curiosity about learning, (2) you can do this by establishing democratic relationship with students and by facilitating rather than directing their learning, (3) intervention with difficult behaviour is a problem solving process rather than an attempt to punish a miscreant, (4) to solve problem, you will use the communication skills of listening to students who are in need, being assertive when your own needs are not being met, and collaborating to solve a problem that is interfering with both your own and your students' needs.

Teori humanistik merekomendasikan beberapa perubahan yang fundamental dalam filosofinya, yaitu cara mengorganisasikan sekolah dan kelas. Sebagai guru, disarankan memiliki keahlian dan pengetahuan yang luas untuk memfasilitasi dan mendorong anak-anak dalam menemukan sesuatu. Isi kurikulum dan proses pembelajaran disesuaikan dengan kebutuhan anak. Hal ini akan mengurangi tingkah aku anak yang mengganggu. Pada kesempatan lain, guru dapat memberikan intervensi pada anak yang mengganggu dengan memberikan tugas yang mengarahkan pada pemecahan masalah dengan menggunakan kemampuan komunikasi. Teori Humanistik menggambarkan beberapa keuntungan, yaitu mendengarkan anak-anak, melibatkan emosi yang baik pada anak dan meningkatkan motivasi dalam belajar (Rogers, 1951; Rogers dan Freiberg, 1994). Kekurangtegasan adalah cara guru dalam meyakinkan dan melindungi anak secara seimbang, dan mengkolaborasikan pemecahan masalah yang bertujuan untuk menemukan solusi yang lebih baik tanpa merendahkan anak atau guru. Meskipun demikian, guru humanistik 
tidaklah sempurna: memerlukan waktu yang lama untuk menjadi cakap atau memiliki keahlian dalam menggunakan pendekatan pemecahan masalah (Gartrell, 1998). Guru humanistik adalah manusia biasa yang mungkin saja melakukan kesalahan seperti juga anak-anak, tujuannya adalah guru belajar dari diri sendiri dan anak-anak (Gartrell, 1998). Intervensi humanistik dengan gangguan tingkah laku: (1) membuat arahan, bukan peraturan, (2) memecahkan masalah: mendengarkan masalah anak dan mengerti kebutuhannya, tegas ketika anak meremehkan kebutuhan guru atau anak lain, menggunakan langkah-langkah kolaborasi pemecahan masalah ketika kebutuhan guru dan anak tidak bertemu, (3) Jika dibutuhkan dan sebagai jalan terakhir menggunakan konsekwensi logis (dalam kesadaran bahwa hal yang merugikan tidak akan terulang lagi dengan pemberian hukuman).

7. Choice Theory has key points: (1) students will be motivated to do high quality work and to behave responsibility if schools are democratic and curricula are relevant to - that is, meet the needs - of students, (2) these needs are survival, love and belonging, power, freedom and fun, (3) in order to meet these needs, the most fundamental change to schools will be a move from bossing students to leading them.

Pendekatan Glasser membutuhkan revisi fundamental pada isi dan proses pembelajaran di sekolah. Hal ini dimulai dari meyakinkan anakanak bahwa sekolah adalah tempat yang baik dimana anak dapat memenuhi kebutuhannya. Berdasarkan pada perasaan anak-anak, guru hendaknya memberikan harapan dan dukungan tingkah laku yang bertanggung jawab dan memiliki kualitas kerja yang tinggi dalam menawarkan kurikulum yang relevan dan memimpin anak-anak. Kepuasan kebutuhan anakanak akan tercapai selama guru mengembangkan kehangatan kerjasama dan membantu perkembangan anak dalam kelompok. Pada anak yang memiliki gangguan tingkah laku, Glasser merekomendasikan pemecahan masalah secara kolaboratif segera dalam kontribusi yang cukup tenang dalam proses ini. Prinsip demokrasi Glasser adalah memperluas kerjasama anak dan guru, melibatkan hirarki sekolah dan semua anggota sekolah. Prinsip tersebut membutuhkan loyalitas para staff dan kemampuan anak-anak dalam membuat keputusan yang bertanggung jawab.
8. Systems Theory has key Points: (1) system theory provides a framework for thinking about recurring problem in new ways, (2) there are four main branches of system theory; the one highlighted in this chaptersolution focused therapy - believes that behaviour problem arise when behaviour is accidentally mishandled and so an attempted solution has not worked, (3) change, then, is brought about by changing how the behaviour is handled. To do this, you need to identify previous solution attempts and do something different from those.

Perspektif system adalah lingkaran pandangan tentang dunia. Jika pada teori psikologi individual melihat individu sebagai keseluruhan dari bagianbagian, sedangkan teori system melihat individu sebagai bagian dari keseluruhan. Robinson (1980: 187) mengkonfirmasikan hal ini bahwa keseluruhan adalah sejumlah bagian-bagian dan mengatakan "Percobaan untuk mengerti keseluruhan dengan memasuki komponen "bagian-bagian" akan selalu tidak ditemukan kerjasama antara bagian-bagian dan kualitas interaksi mereka". Walaupun banyak pendekatan teori system yang dapat diperluas menggunakan kerangka teori lain dalam teks ini, Monar dan Lindquist (1989) menyarankan untuk bersandar pada ide-ide yang telah disampaikan. Mereka menegaskan penggunaan ide dari teori dasar individu dapat mengabadikan gambaran masalah tingkah laku dalam mengurus solusi dan masalah. Bahkan teori ini tidak menyarankan solusi, guru akan mencoba sesuatu yang berbeda. Shazer dkk (1986: 212) menyatakan (1) jika sesuatu bekerja, lakukan lebih dari itu (melihat harapan), (2) jika sesuatu tidak sedang bekerja, hentikan (kurangi hal yang sama), (3) jika sesuatu tidak sedang bekerja, lakukan sesuatu yang lain (lakukan sesuatu yang berbeda).

9. Critique of the Theories has key points: (1) all theories say that they are effective - that is, they meet their goals. The question to ask is: what are their goals? (2) discipline policies and practices in schools are not selected in a vacuum but within the context of a society that marginalizes and silences powerless groups - in this case, young people, (3) thus, while all theories have their strengths, we need to consider also what negative side - effects they may provoke for the recipients of their measures.

Johnson dkk (1994) menyarankan dan mengkritik bahwa percobaan mengungkapkan nilai, asumsi, dan kontradiksi mendasari disiplin sekolah secara 
praktis. Kritiknya menduga bahwa guru hendaknya mempertimbangkan tidak hanya merekomen-dasikan pengaruh yang kuat pada disiplin anak-anak secara praktis, tetapi juga merekomendasikan pengaruh kedua, yaitu perasaan anak-anak seperti layak, tanggung jawab, kemampuan pebelajar yang dapat memecahkan masalah dan melatih control diri (Curwin dan Mendler, 1988)

Tabel Kekuatan dan Kelemahan pada masingmasing Teori Pengelolaan Tingkah Laku pada Anak-anak

\begin{tabular}{|c|c|}
\hline Kekuatan & Kelemahan \\
\hline \multicolumn{2}{|l|}{$\begin{array}{l}\text { Limit - setting approaches } \\
\text { Rekomendasi praktis }\end{array}$} \\
\hline Rekomendasi praktis & Bersifat otoriter \\
\hline & $\begin{array}{l}\text { Beberapa pencatatan pengaruh negatif } \\
\text { pada anak-anak }\end{array}$ \\
\hline & Tidak berdasarkan pada teori pendidikan \\
\hline \multicolumn{2}{|l|}{ Applied behaviour analysis } \\
\hline Pengamatan tidak memihak & Bersifat otoriter \\
\hline \multirow[t]{7}{*}{ Metode tepat } & Komponen pencegahan sempit \\
\hline & Mengabaikan penyebab tingkah laku \\
\hline & $\begin{array}{l}\text { Menggunakan bahasa golongan tertentu } \\
\text { yang kompleks }\end{array}$ \\
\hline & $\begin{array}{l}\text { Sedikit kemungkinan untuk bekerja } \\
\text { dalam kelompok daripada individu }\end{array}$ \\
\hline & Pengaruh negatif pada pembelajaran \\
\hline & Pemeliharaan keuntungan yang ragu-ragu \\
\hline & Masalah etika \\
\hline \multicolumn{2}{|l|}{ Cognitive - behavioursm } \\
\hline Meningkatkan motivasi anak & $\begin{array}{l}\text { Mempunyai sifat otoriter dengan suara } \\
\text { lemah }\end{array}$ \\
\hline $\begin{array}{l}\text { Meningkatkan pendidikan dan outcome } \\
\text { tingkah laku }\end{array}$ & $\begin{array}{l}\text { Lebih tidak jelas daripada Applied } \\
\text { behaviour analysis }\end{array}$ \\
\hline \multirow[t]{3}{*}{$\begin{array}{l}\text { Menanggulangi beberapa dilemma etika } \\
\text { pada Applied behaviour analysis }\end{array}$} & $\begin{array}{l}\text { Kepercayaan terus menerus pada metode } \\
\text { tingkah laku }\end{array}$ \\
\hline & $\begin{array}{l}\text { Anak-anak tidak boleh dimotivasi untuk } \\
\text { berpartisipasi dalam mengelola diri }\end{array}$ \\
\hline & $\begin{array}{l}\text { Membutuhkan anak-anak yang memiliki } \\
\text { kemampuan verbal }\end{array}$ \\
\hline \multirow{2}{*}{\multicolumn{2}{|c|}{ Neo - Adlerian theory }} \\
\hline & \\
\hline Mendorong anak & Kebutuhan emosi kurang dikembangkan \\
\hline Menjelaskan preskriptif untuk aksi & Harapan yang tidak realistic untuk anak- \\
\hline \multirow[t]{9}{*}{ Pelatihan orangtua } & $\begin{array}{l}\text { anak } \\
\text { Tidak ada bukti untuk tujuan tingkah laku }\end{array}$ \\
\hline & yang salah \\
\hline & Diagnosis subjektif pada tujuan \\
\hline & $\begin{array}{l}\text { Tidak menghargai pengetahuan dalam } \\
\text { diri anak }\end{array}$ \\
\hline & Penamaan negatif pada individu \\
\hline & Menggunakan konsekwensi/hukuman \\
\hline & \\
\hline & Kritikan orangtua \\
\hline & Kekurangan pada fokus social \\
\hline \multicolumn{2}{|l|}{ Humanism } \\
\hline \multirow{2}{*}{$\begin{array}{l}\text { Fokus pencegahan } \\
\text { Pandangan positif pada individu }\end{array}$} & Beberapa intervensi tingkah laku segera \\
\hline & Anak-anak boleh mengawali test \\
\hline \multirow[t]{2}{*}{ Mempromosikan tanggung jawab diri } & $\begin{array}{l}\text { keterpaduan guru } \\
\text { Membutuhkan guru yang memiliki }\end{array}$ \\
\hline & kemampuan berkomunikasi \\
\hline Meningkatkan pembelajaran & $\begin{array}{l}\text { Anak-anak membutuhkan kemampuan } \\
\text { verbal }\end{array}$ \\
\hline \multirow{2}{*}{\multicolumn{2}{|c|}{$\begin{array}{l}\text { Mengalamatkan penyebab mendasar pada } \\
\text { anak-anak }\end{array}$}} \\
\hline & $\begin{array}{l}\text { anak-anak } \\
\text { Ketidakpuasan }\end{array}$ \\
\hline \multicolumn{2}{|l|}{ Kehidupan demokrasi } \\
\hline \multicolumn{2}{|l|}{ Choice theory } \\
\hline Mempromosikan tanggung jawab diri & $\begin{array}{l}\text { Membutuhkan guru yang memiliki } \\
\text { kemampuan komunikasi }\end{array}$ \\
\hline $\begin{array}{l}\begin{array}{l}\text { Memasukkan } \\
\text { perhitungan }\end{array} \\
\text { konteks }\end{array}$ & $\begin{array}{l}\text { Anak-anak membutuhkan kemampuan } \\
\text { verbal }\end{array}$ \\
\hline Menghilangkan tekanan konflik guru dan & \\
\hline \multicolumn{2}{|l|}{$\begin{array}{l}\text { anak } \\
\text { Kemampuan aplikasi yang luas }\end{array}$} \\
\hline \multirow{2}{*}{\multicolumn{2}{|c|}{$\begin{array}{l}\text { Menambah intervensi konseling seorang } \\
\text { humanist dasar }\end{array}$}} \\
\hline & \\
\hline Kehidupan demokrasi & \\
\hline Pendekatan efektif pada keseluruhan & \\
\hline komponen sekolah & \\
\hline System theory & \\
\hline Aplikasi masalah kronis & Teori kompleks \\
\hline Menghormati individu & $\begin{array}{l}\text { Intervensi individu sulit untuk praktisi } \\
\text { yang baru merancang pembelajaran }\end{array}$ \\
\hline Fokus yang luas & Membuka ketidaktulusan hati \\
\hline Optimis pada potensi perubahan & \\
\hline Fasilitas solusi baru & \\
\hline Menggunakan humo & \\
\hline
\end{tabular}

\section{Bagian 2: Motivating Students}

10. Safeguarding Students has key points: (1) learning will not be a high priority for students whose physical needs are not met, (2) you can take steps to ensure that the class and overall school environment promote high achievement and considerate behaviour, (3) these measures include establishing an ethos that honours diversity in students and protects them from intimidation by others.

Jika anak-anak merasa aman secara fisik dan psikis di sekolah, maka anak-anak akan diikutsertakan dalam pekerjaan akademik. Jika anak memiliki keinginan lain, maka guru hendaknya mempertimbangkan etos sekolah dan pengukuran praktis yang akan menggambarkan perasaan baik pada anak-anak, untuk meningkatkan keuntungan individu dan komunitas sekolah.

11. Satisfying Students' Need for Autonomy has key points: (1) fundamental to all human beings is the need to be in control of ourselves, (2) you can meet this need in you students, both through how you teach and through your response to their behaviour.

Anak-anak akan belajar lebih baik jika mereka mengerti kebutuhannya dan isi kurikulum, serta proses pembelajaran yang mendorong mereka secara aktif. Guru hendaknya dapat meyakinkan anak bahwa mereka memiliki otonomi dan pembelajaran yang menyenangkan akan membantunya meningkatkan motivasi belajar.

12. Fostering Competence has key points: (1) students will be motivated to participate in learning and to behave considerately when they anticipate that they can be successful at school, (2) when they become competent at worthwhile skills, their self-esteem will rise, which in turn will make them more willing to take intellectual risks in future, (3) feedback that inform them about their achievement is more likely to encourage continued effort than are judgments about them or their work.

Pertimbangan penelitian tentang tubuh menilai bahwa kebutuhan anak-anak pada perkembangan emosi dan akademik memiliki arti pencegahan terhadap gangguan tingkah laku di sekolah (Grossman, 1995; Jones dan Jones, 1998). Meskipun demikian, strategi untuk menciptakan iklim kelas yang positif tetap tidak cukup dari anak-anak: guru hendaknya memberikan tambahan pada anak-anak dalam akademik secara bijaksana dan informal (kindsvatter dkk, 1992). Dengan demikian anak-anak dapat mencapai tujuannya dan state of mind not just another additional task to add to your 
mengembangkan kemampuan yang berguna. Hal ini akan meningkatkan kesehatan harga dirinya

13. Meeting Students' Social Needs has key points: (1) schools need to rearrange their priorities to focus on students' relationships with each other, as well as their present emphasis on students - teachers relationships, (2) you can establish warm relationships with your students by being open with them and by communicating your care for their achievements and personal development, (3) you can facilitate the social inclusion of isolated students by instituting cooperative activities and by offering a social skills curriculum.

Anak-anak yang selalu membina kerjasama dengan guru, menginginkan guru dapat mendengarkan mereka dan mendorong pertumbuhan mereka secara terus menerus. Seperti iklim emosi, anak-anak lebih suka mencapai sesuatu lebih baik dan akan menguasai bentuk kerjasama satu sama lain. Pertemanan memberikan banyak keuntungan, termasuk menyelamatkan anak-anak dari kesendirian. Anak-anak yang tertutup tidak termasuk dalam keuntungan pertemanan dan berada pada bahaya ketidakbahagiaan pada masa sekarang dan akan datang (walaupun guru harus mengingat bahwa hubungan ini bukanlah penyebab/akibat kebutuhan). Tidak semua anak memiliki kemampuan sosial yang baik (bentuk kerjasama tertutup, perasaan sia-sia atau ditolak). Hal ini menandakan bahwa anak tersebut memiliki percaya diri yang rendah. Kemampuan sosial lebih dari sekedar pengetahuan. Kemampuan social membutuhkan berpikir ke dalam diri yang baik dan mampu menggunakannya sesuai pada tempatnya berdasarkan kesadaran pada konteks sosial dan kebutuhan orang lain. Oleh karena itu melatih kemampuan sosial tidak sekedar dapat memberikan instruksi dalam tingkah laku yang lebih luas tetapi keyakinan bahwa lingkungan memberikan fasilitas tingkah laku prososial, meningkatkan kemampuan emosi dan kognitif lebih baik. Metode latihan berbeda pada setiap anak dengan usia yang berbeda dalam memberikan instruksi, latihan, umpan balik, penguatan pendekatan tingkah laku, dan melakukan latihan yang berulang-ulang.

\section{Bagian 3: Beyond the Classroom}

14. Collaborating with Parents has key points: (1) collaboration with parents and other professionals is a many others, (2) the goal collaboration is to empower parents to act in their children's interests, to empower you to meet your students' needs at school, and to empower students to contribute to problem solving, (3) although, because of your professional status, it could be assumed that you make all educational decisions, parents also have skills and knowledge to contribute to the planning of services for their children. Even when these skills are not readily apparent, systems theory reminds us that people always do the best they can in the circumstances; by respecting parents, you can improve their personal circumstances and correspondingly enable them to act more successfully. Walaupun banyak rintangan dalam membina hubungan antara orangtua dan guru namun hendaknya keduanya memiliki ikatan dalam melakukan yang terbaik untuk anak. Guru boleh memiliki perbedaan pendapat dengan orangtua dalam melakukan yang terbaik untuk anak-anak tetapi keduanya hendaknya memiliki satu tujuan, yaitu berbuat baik yang dikomunikasikan dengan baik pula selama membina kerjasama dan saling memberikan informasi. Hal ini akan memperkaya hubungan kerjasama dan dapat mempromosikan outcomes anak-anak lebih baik.

15. Formulating a Discipline Policy has key points: (1) whether at a personal or a school needs to have clear philosophy goals, theory base and guidelines for practice, (2) proactive measures will be given most emphasis in such policy because prevention of problems is more powerful than intervention, (3) policies must take into account the requirement of teachers, students, parents and school administrators.

Walaupun perumusan kebijakan harus segera diselesaikan, proses pembelajaran memberikan kesempatan pada semua partisipan untuk menjelaskan tentang nilai, peran, dan tanggung jawabnya (Stonehouse, 1991). Sekolah formal dengan kebijakan yang lebih luas memiliki keuntungan, yaitu guru tidak banyak tingkah walaupun guru memiliki otonomi yang ideal (Cangelosi, 1997; Farmer, 1995; Good and Brophy, 1986). Proses perkembangan kebijakan mengharapkan guru tidak tergesa-gesa dalam membuat keputusan terhadap masalah yang sudah terjadi. Sekolah dengan kebijakan luas sebaiknya dapat merumuskan tingkah laku anakanak. Sekolah dengan kebijakan yang luas akan membantu guru dalam memecahkan masalah disiplin (Charles, 1999). Dokumentasi tulisan juga membantu sekolah (tentang filosofi dan pekerjaan 
di sekolah) dalam merekrut staff baru dan orangtua. Ketika kebijakan sekolah muncul melalui forum diskusi, hendaknya dapat diterima dan tersebar luas serta didukung oleh tingkat tertinggi di sekolah dan kelompok orangtua. Kesadaran membantu dapat dilakukan oleh guru dari hari ke hari di dalam kelas.

\section{DAFTAR PUSTAKA}

Adler, A. (1957). Understanding human nature Fawcett. New York.

Alberto, P. A., \& Troutman, A.C. (1999). Applied behaviour analysis for teachers. ( $5^{\text {th }}$ ed). New Jersey: Merril Upper Saddle River

Brophy, J., \& Good, T.L. (1986). Teacher behavior and student achievement in Handbook of Research on Teaching. ( $3^{\text {rd }}$ ed). New York: M.C. Wittrock Macmillan

Cangelosi, J. S. (1997). Classrooom management strategis: gaining and maintaining students' cooperation. $\left(3^{\text {rd }}\right.$ ed) New York: Longman.

Canter, L., \& Canter, M. (1976). Assertive discipline: A take charge approach for today's. Educator Lee Canter Record. Vol. 90. No. 4

(1992). Assertive Discipline: Positive behavior management for todays. Santa Monica: Classroom Lee Canter and Associates

Charles, C. M. (1999). Building classroom discipline: From models to practice. ( $6^{\text {th }}$ ed). New York: Longman.

Curwin, R.L. and Mendler, A.N. (1988). Package discipline programs: let the buyer beware' educational leadership. Vol. 46 No. 2

(1989). We repeat, let the buyer beware: A response to canter educational leadership. Vol. 46. No. 6.

Farmer, S. (1995). Policy development in early childhood services community child care. Sidney: Cooperative Ltd.

Foster, M., Berger, M., \& Mclean, M. (1981). Rethingking a good idea: a reassesment of parents involvement. Topics in Early childhood special education. Vol. 1 No. 3

Gartrell, D. (1998). A guidance approach for the encouraging classroom $2^{\text {nd }} e d n$. New York: Delmar Albany

Grossman, H. (1995). Classroom behavior management in a diverse society. $\left(2^{\text {nd }} \mathrm{ed}\right)$. Mayfield: Mountain View CA.

Glasser. (1998). Choice theory. New York: Harper Perennial
Johnson, B., Whittington, V., \& Oswald, M. (1994). Teachers views on school discipline: a theoretical framework. Cambridge Journal of Education. Vol. 24. No. 2.

Jones, V.F., \& Jones, L.S. (1990). Comprehensive classroom management: Motivating and managing students. ( $\left.3^{\text {rd }} \mathrm{ed}\right)$. Boston: Allyn and Bacon.

(1998). Comprehensive classsroom management: Creating communities of support and solving problems. ( $5^{\text {th }}$ ed). Boston: Allyn Bacon.

Kaplan, J. S., \& Carter J. (1995). Beyond behavior modification: A cognitive-behavioral approach to behavior management in the school. ( $3^{\text {rd }}$ ed). Austin: Pro-Ed.

Kindsvatter, R., Wilen, W. and Ishler, M. (1992). Dynamics of effective teaching $2^{\text {nd }} e d n$. New Jersey: Merrill-Upper Saddle River.

Lindquist, B., Molnar, A., \& Brauchman, L. (1987). Working with school related problems without going to school: Consideration for systemic practice. Journal of Strategic and Systemic Therapies Vol 6 No. 4.

Molnar, A., \& Lindquist, B. (1989). Changing problem behaviour in school. San Fransisco, CA: JosseyBass.

Robinson, M. (1990). Systems theory for the beginning therapist. Australian Journal of Family Therapy Vol. 1 No. 4

Rogers, C. R., \& Freiberg, H. (1994). Freedom to learn $\left(3^{\text {rd }}\right.$ ed). New York: Merrill.

Stonehouse, A. (1991). Opening the door: Child care in a multicultural society. Watson: Australian Early Childhood Association.

Zirpoli, T. J., \& Melloy, K. J. (1997). Behavior management: Application for teachers and parents $\left(2^{\text {nd }}\right.$ ed). Merrill-Upper Saddle River.

\section{KETERANGAN PENULIS}

Rr. Sri Indah Pujiastuti Kartosendjoyo Diponegoro, S.Twf, M.Pd, lahir di Jakarta tahun 1975. Menyelesaikan pendidikan terakhirnya di program S2 S2 Pendidikan Anak Usia Dini Universitas Negeri Jakarta. Saat ini aktif sebagai staf pengajar di Dosen Tetap Program Studi Pendidikan Anak Usia Dini FIP UNJ setelah sebelumnya berkecimpung selama beberapa tahun menjadi guru (1995-2000). Salah satu karyanya yaitu Kesiapan Bersekolah Murid Kelas 1 SD yang melalui TK dan Tidak melalui TK (Kerjasama Puskur Balitbang, Depdiknas RI, 1999), Lembar Kerja untuk Anak TK (Kerjasama Penerbit Ganesha, 2006). 